\title{
PENGARUH LKS IPA TERPADU BERMUATAN LITERASI TEMA GERAK DALAM MODEL PEMBELAJARAN KONTEKSTUAL ADAPTIF TERHADAP KOMPETENSI SISWA KELAS VIII SMPN 15 PADANG
}

\author{
Dwiyan Hari Ramadhan ${ }^{1)}$, Djusmaini Djamas ${ }^{2)}$, Asrizal Asrizal ${ }^{2)}$ \\ ${ }^{1)}$ Mahasiswa Pendidikan Fisika, FMIPA Universitas Negeri Padang \\ ${ }^{2)}$ Staf Pengajar Jurusan Fisika, FMIPA Universitas Negeri Padang \\ dwiyanhariramadhan@gmail.com \\ djusmainidjamas@yahoo.co.id \\ asrizal_unp@yahoo.com
}

\begin{abstract}
Integrated science teaching should be implemented well in Junior High School. In addition, school literacy movement needs to be developed to improve literacy of students. But the real conditions show that the integration of science teaching material and literacy of students were still low. The solution of this problem was to use the integrated science student worksheet by integrating digital age literacy in adaptive contextual teaching model. The purpose of the research was to investigate the influence of integrated science student worksheet by integrating the digital age literacy on motion theme in our live toward the competence of grade VIII students in SMPN 15 Padang. The type of research which conducted was quasi-experimental research. The research design was randomized control-group only design. The research population was all students of grade VIII SMPN 15 Padang which registered in academic year in 2017/2018. Sampling technique in this research was purposive sampling. The samples in this research were grade VIII 5 students as the experimental group and grade VIII 7 students as the control group with the total of samples were 64 students. The research instruments consist of observation sheet to assess attitudes, test result sheet to assess knowledge, and performance assessment sheet to assess skill of student. Research data were analyzed by using descriptive analysis and comparison test. From the analysis of data can be stated that the use of Integrated science student worksheet by integrating the digital age literacy of motion theme in our life in adaptive contextual teaching model gives a significant effect on the knowledge, the attitude and the skills competences of grade VIII students in SMPN 15 Padang at $95 \%$ confidence level.
\end{abstract}

Keywords : Student worksheet, Integrated science, Contextual teaching, Teaching model

\section{PENDAHULUAN}

Abad ke-21 ditandai sebagai abad keterbukaan atau globalisasi. Kehidupan manusia pada abad ke-21 mengalami perubahan-perubahan yang fundamental yang berbeda dengan tata kehidupan dalam abad sebelumnya. Abad ini dikatakan abad yang meminta kualitas dalam segala usaha dan hasil kerja manusia. Abad ke-21 dengan sendirinya meminta sumber daya manusia (SDM) yang berkualitas, yang dihasilkan oleh lembaga yang dikelola secara profesional sehingga memperoleh hasil yang unggul.

Peran literasi sangat diperlukan dalam men jawab tantangan pendidikan abad ke-21. Literasi membuat manusia peka terhadap lingkungan dan dapat mengikuti perkembangan zaman di era global isasi. Manusia dapat memahami dan menggali ke terkaitan antara yang satu dengan yang lain. Jadi lite rasi merupakan salah satu upaya yang dapat diguna kan untuk menjawab tantangan abad ke-21 dalam me ngatasi pergeseran paradigma pendidikan dan mem persiapkan kompetensi siswa yang diinginkan.

Upaya yang dilakukan pemerintah untuk mencapai tujuan pendidikan adalah telah dilakukan penyempurnaan Kurikulum Tingkat Satuan Pendidi kan (KTSP) menjadi Kurikulum 2013. Kurikulum 2013 bertujuan untuk membentuk generasi yang memiliki kompetensi prngrtahusn, sikap, dan kete rampilan yang lebih produktif, kreatif, dan inovatif. Pemerintah juga berupaya meningkatkan literasi sis wa melalui program Gerakan Literasi Sekolah (GLS). GLS menjadikan sekolah sebagai organisasi yang mampu mengakses, memahami, dan menggunakan aktivitas melalui proses membaca, menulis, melihat, dan menyimak $^{[1]}$.

Literasi adalah kemampuan individu untuk membaca, menulis, berbicara, menghitung, dan me mecahkan masalah pada tingkat keahlian (melek) yang diperlukan dalam pekerjaan, keluarga, dan masyarakat. Unesco mengatakan seseorang dapat di sebut literate apabila ia memiliki pengetahuan yang hakiki untuk digunakan dalam setiap aktivitas yang menuntut fungsi literasi secara efektif dalam mas yarakat dan pengetahuan. Salah satu kelompok literasi yang digunakanadalah literasi era digital ${ }^{[2] \text {. }}$

Literasi era digital adalah kemampuan untuk mencapai kesuksesan di abad ke 21 dalam cakupan membaca, menulis, dan menghitung sederhana yang dianggap melek huruf, siswa perlu mencapai ke mahiran atas Sains, teknologi, dan budaya serta 
mendapatkan pemahaman menyeluruh tentang infor masi dalam segala bentuk ${ }^{[3]}$. Ada tujuh kajian dari literasi era digital yaitu, literasi fungsional, literas saintifik, literasi ekonomi, literasi teknologi, literasi visual, literasi informasi, dan literasi budaya ${ }^{[1]}$. Ting kat SMP literasi era digital yang tepat digunakan adalah literasi fungsional, literasi saintifik, dan lite rasi visual karena ketiga literasi ini dapat diterapkan didalam LKS yang dimiliki siswa ${ }^{[3]}$.

Kurikulum 2013 pada jenjang pendidikan SMP/MTs dalam pembelajaran IPA dilakukan deng an konsep integratif Sains atau IPA terpadu. Konsep keterpaduan ditunjukan pada penyajian materi IPA. Pada IPA dijelaskan bahwa setiap kemampuan IPA diperoleh dari kegiatan atau proses ilmiah. Di dalam kegiatan dan proses ilmiah di dasarkan pada metode ilmiah. Melalui pembelajaran IPA, diharap kan siswa dapat memperoleh pengetahuan secara ilmiah, dapat bekerjasama dalam tim, dapat menambah kekuatan untuk menerima, menyimpan, dan menerapkan kon sep yang dipelajarinya ${ }^{[4]}$. Pembelajaran terpadu yang dikemas dengan tema dan topik tentang suatu wacana akan dibahas dari berbagai sudut pandang atau disiplin ilmu yang mudah dipahami dan dikenal sehingga menciptakan suatu pembelajaran yang bermakna $^{[4]}$.

Studi awal yang diakukan belum menggambar kan kondisi yang diharapkan, tetapi mengindikasi kan terdapat permasa lahan. Studi awal diperoleh dari wawancara dan analisis menunjukkan pelaksana an pembelajaran IPA terpadu, penggunaan LKS di sekolah, pelaksanaan literasi di sekolah, dan hasil ujian akhir semester siswa masih terdapat per masalahan. Jadi ada empat hasil studi yang ditemu kan di lapangan.

Dari studi awal yang telah dilakukan dapat dikemukakan empat hasil. Pertama dari hasil wa wancara yang dilakukan dengan dua orang guru IPA SMPN 15 Padang bahwa pembelajaran terpadu ma sih dilakukan terpisah, belum optimal, media yang digunakan dan sumber belajar masih kurang. Kedua, hasil analisis keterpaduan LKS didapatkan keterpa duan LKS IPA Fisika dan LKS IPA Biologi MGMP sebesar $41,67 \%$. Ketiga, hasil rata-rata literasi yang dimiliki siswa adalah 47,45\%. Terakhir rata-rata hasil ujian akhir semester januari-juli 2017 adalah 44,19 masuk kedalam tegori rendah.

Adanya kesenjangan antara kondisi ideal dan kondisi nyata menggambarkan adanya masalah da lam penelitian. Permasalahan yang ada yaitu pelak sanaan pembelajaran IPA terpadu, penggunaan LKS di sekolah, pelaksanaan literasi di sekolah, dan hasil ujian akhir semester siswa. Solusi dari permasalah adalah penggunaan LKS IPA terpadu bermuatan literasi era digital tema gerak dalam model kon tekstual adaptif terhadap kompetensi siswa.

LKS merupakan salah satu bahan ajar yang dapat digunakan pada penerapan pembelajaran IPA terpadu. LKS adalah panduan siswa yang digunakan untuk kegitan penyelidikan atau pemecahan masalah. LKS dikatakan sebagai lembaran-lembaran berisi tugas yang harus di kerjakan oleh siswa ${ }^{[4]}$. LKS dapat berisi tentang panduan latihan dan panduan eks perimen yang harus dikerjakan siswa.

LKS digunakan sebagai pendukung dalam melaksanakan pembelajaran sesuai tuntutan kuriku lum 2013. LKS dapat dijadikan salah satu solusi dalam menjawab tantangan pendidikan abad-21. LKS memiliki tujuan yaitu, 1) membuat siswa menemu kan konsep, 2) mengintegrasikan berbagai konsep, 3) penuntun belajar, 4) memberi penguatan, 5) memberi petunjuk eksperimen, dan 6) mempersiapkan siswa untuk belajar sebelum proses pembelajaran. Keenam uraian meru pakan tujuan LKS. LKS mampu untuk membuat pembelajaran berpusat pada siswa. Fungsi LKS antara lain membuat siswa aktif, membuat siswa melakukan penyelidikan, sebagai penuntun belajar, sebagai penguatan terhadap materi yang di pelajari, dan sebagai petunjuk siswa dalam melaku kan kegiatan praktikum ${ }^{[5]}$.

Literasi dalam bahasa Inggris disebut dengan Licteracy yang berasal dari bahasa latin littera (huruf) yang pengertiannya melibatkan penguasaan sistem-sistem tulisan dan konvensi-konvensi yang menyertainya. Menjawab tantangan abad ke 21 maka literasi yang digunakan yaitu literasi era digital. Kajian literasi yang akan dibahas dari literasi era digital adalah literasi fungsional, literasi saintifik, dan literasi visual.

Literasi fungsional adalah kemampuan untuk mendengarkan, berbicara, membaca, menulis, dan menghitung, berkaitan dengan kemampuan analisis untuk memperhitungkan, mempersepsikan informasi, mengkomunikasikan, serta menggambarkan inform asi berdasarkan pemahaman dan pengambilan kesi mpulan pribadi ${ }^{[6]}$. Literasi ini merupakan dasar yang harus dimiliki siswa dalam pendidikan. Indikator literasi fungsional adalah menulis, menggambarkan informasi, menghitung, dan menggambar.

Literasi saintifik didefenisikan sebagai kappa sitas untuk menggunakan pengetahuan ilmiah ${ }^{[2]}$. Lite rasi saintifik dapat dikatakan sebagai pengetahuan dan pemahaman tentang konsep-konsep ilmiah dan proses ilmiah. Indikator literasi saintifik adalah konsep saintifik, proses saintifik, dan konteks sain tifik siswa $^{[7]}$

Literasi visual adalah literasi yang yang menggambarkan (melek) visual seseorang. Literasi visual berfokus pada penafsiran gambar visual se seorang yang juga terkait dengan kemampuan mem baca dan kemampuan menulis ${ }^{[6]}$. Indikator literasi visual adalah menafsirkan visual dan meman faatkan visual yang dimiliki siswa.

Model pembelajaran kontekstual adaptif atau MPKA adalah kerangka konseptual yang melukiskan prosedur yang sistematis dalam mengorganisasikan pengalaman belajar untuk mencapai tujuan belajar tertentu, dan berfungsi sebagai pedoman bagi pen 
didik dalam merencanakan dan melaksanakan kegiatan pembelajaran yang mampu menghubungkan materi pembelajaran dengan situasi dunia nyata siswa. Model kontekstual adaptif merupakan kom binasi antara model pembelajaran dan pembelajaran kontekstual. Adaptif dalam model ini memiliki arti sebagai adaptasi model dan menggunakan termino logi pembelajaran. Model pembelajaran kontekstual adaptif lebih menekankan pada kontruksi penge tahuan dan mengkaitkan materi pembelajaran deng an situasi nyata siswa ${ }^{[8]}$.

MPKA memiliki empat tujuan pembelajaran. Pertama, membantu siswa untuk menghubungkan materi pembelajaran sesuai dengan situasi dunia nyata siswa. Kedua, membantu guru untuk mem bantu siswa belajar. Ketiga, membantu siswa untuk mebuat pembelajaran bermakna bagi siswa. Keem pat, membantu siswa untuk aktif dalam belajar dengan cara meningkatkan keterlibatan siswa dalam proses pembelajaran $^{[9]}$.

LKS yang digunakan adalah LKS IPA ter padu tema gerak bermuatan literasi yang diteliti oleh Esti (2016), serta telah dilakukan validasi dan prak tikalitasnya. Nilai rata-rata validasi oleh tenaga ahli yaitu 84.8, sedangkan nilai rata-rata praktikalitas oleh guru yaitu 90.3, dan nilai rata-rata praktikalitas oleh siswa $90.3^{[10]}$. Keterbatasan LKS hanya diguna kan sampai uji terbatas maksudnya diujikan hanya pada beberapa siswa sehingga peneliti akan menggunakan LKS secara menyeluruh ketika proses pembelajaran.

Berdasarkaan latar belakang yang dijabarkan, peneliti tertarik untuk mengunakan LKS IPA terpadu bermuatan literasi era digital untuk pembelajaran siswa SMP. Keuntungan dari penggunan LKS adalah pembelajaran terpusat pada siswa. Dengan bermuatan literasi era digital dalam LKS, diperkirakan dapat meningkatkan kompetensi siswa. Dengan alasan ini peneliti tertarik untuk melakukan penelitian dengan tujuan menye lidiki pengaruh penggunakan LKS IPA terpadu bermuatan literasi era digital terhadap kom petensi siswa kelas VIII SMPN 15 Padang.

\section{METODE PENELITIAN}

Jenis penelitian yang digunakan pada pene litian ini adalah penelitian eksperimen semu. Pemili han jenis penelitian ini karena variabel-variabel luar yang mempengaruhi pelaksanaan kegiatan ekspe rimen tidak bisa dikontrol ${ }^{[11]}$. Rancangan penelitian yang akan digunakan menggunakan desain hanya kelompok kontrol ternormalisasi.

Dalam penelitian ini dibutuhkan dua kelas, yaitu kelas kontrol dan kelas eksperimen, dimana pada kelas eksperimen diberikan perlakuan dengan menerapkan LKS IPA Terpadu bermuatan literasi era digital tema gerak, dan pada kelas kontrol digunakan bahan ajar yang biasa digunakan di sekolah. Tabel 1 .
Tabel 1. Desain Hanya Kelompok Kontrol Ternorma lisasi

\begin{tabular}{|c|c|c|}
\hline Group & Treatment & Post test \\
\hline Eksperimen & $\mathrm{X}$ & $\mathrm{T} 2$ \\
\hline Kontrol & & $\mathrm{T} 2$ \\
\hline
\end{tabular}

Keterangan :

$\mathrm{X}=$ LKS IPA terpadu bermuatan literasi era digital tema gerak.

$\mathrm{T}_{2}=$ Test akhir sesudah diberi perlakuan.

Variabel penelitian adalah suatu atribut, sifat atau nilai dari orang, objek dan kegiatan yang mem punyai variasi tertentu yang ditetapkan oleh peneliti untuk dipelajari dan kemudian ditarik kesimpul annya ${ }^{[12]}$. Pada penelitian ini telah ditentukan tiga variabel, ketiga variabel yaitu variabel bebas, varia bel terikat, dan variabel kontrol. Variabel bebas dari penelitian ini adalah LKS IPA Terpadu ber muatan literasi era digital tema gerak. Variabel terikat dari penelitian ini adalah pencapaian kompetensi IPA siswa kelas VIII SMPN 15 Padang. Variabel kontrol dalam penelitian ini adalah mata pelajaran dan materi pembelajaran sesuai dengan kurikulum 2013, dan guru yang sama.

Populasi pada penelitian ini adalah seluruh siswa kelas VIII yang terdaftar pada Tahun ajaran 2017/2018. Jumlah siswa keseluruhan 225 siswa. Ni lai rata-rata tertinggi tiap kelasnya yaitu 54,47 pada kelas VIII 1, nilai rata-rata terendah 48,67 pada kelas VIII 2. Jumlah keseluruhan yaitu 55.8.

Sampel dapat dipilih dari populasi yang ada. Sampel adalah sebagian populasi yang diteliti artinya segala karakteristik populasi tergambar dalam sam pel $^{[12]}$. Sampel harus benar-benar dapat berfungsi me nggambarkan keadaan populasi yang sebenarnya, maka pengambilan sampel harus dilakukan meng gunakan teknik pengambilan sampel yang tepat. Tek nik yang digunakan dalam pengambilan sampel ada lah sampel bertujuan.

Sampel bertujuan adalah teknik penentuan sampel dengan pertimbangan tertentu. Sampel pada penelitian ini adalah VIII 5 dan VIII 7. Pengambilan sampel berdasarkan jumlah siswa yang sama yaitu 32 siswa dan nilai rata-rata ujian akhir semster yang hampir mendekati sama yaitu 49,22 dan 50,00.

Tahapan pelaksanaan penelitian dimulai dari tahap persiapan, tahap pelaksanaan, dan tahap penye lesaian. Tahap pelaksanaan dimulai dari menen tukan jadwal penelitian, sampel yang digunakan, dan pe rangkat yang akan digunakan. Pada tahap pelaksa naan harus dipersiapkan skenario yang akan di lakukan sebagai acuan dalam penelitian. Tahap penye lesaian peneliti harus melakukan tes akhir pada kedua kelas sampel, dan mengumpulkan data yang dibutuh kan pada penelitian.

Instrumen pengumpulan data pada penilaian kompetensi sikap menggunakan lembar observasi yang memuat aspek-aspek yang diamati dari sikap siswa selama proses pembelajaran berlangsung. 
Aspek tersebut ditafsirkan berupa skor atau angka, sebagaimana yang ditegaskan oleh Menteri Pen didikan dan Kebudayaan hasil pengukuran berupa skor atau angka ${ }^{[12]}$.

Instrumen kompetensi pengetahuan dari penelitian ini adalah tes objektif berjenis multiple choice test yang dilaksanakan di akhir penelitian. Agar tes menjadi alat ukur yang baik, maka perlu diper hatikan langkah-langkah berikut : 1) membuat kisi-kisi soal uji coba, 2) menyusun soal uji coba berdasarkan kisi-kisi yang telah dibuat sebanyak 90 soal, 3) mela kukan uji coba soal tes akhir yang dilakukan di SMPN 12 Padang. 4) melakukan analisis terhadap uji coba soal test yang telah dilakukan. Dari hasil uji coba ini dilakukan analisis soal untuk memenuhi syarat instru men yang baik. Analisis statistik hasil uji coba test yaitu, validitas, reliabelitas, tingkat kesukaran soal, dan daya beda soal ${ }^{[13]}$.

Instrumen kompetensi keterampilan berhu bungan dengan keterampilan siswa selama mengikuti proses pembelajaran. Penilaian ini dilakukan melalui lembar kinerja, yaitu penilaian yang menuntut siswa mendemonstrasikan suatu kompetensi tertentu. Ins trumen yang digunakan berupa daftar cek atau skala penilaian yang dilengkapi dengan rubrik penilaian kinerja siswa.

Analisis data penelitian dilakukan untuk me nguji kebenaran hipotesis yang diajukan dalam pene litian. Analisis data dilakukan melalu beberapa tahap an seperti analisis deskriptif, tahap persentase, tahap uji persyaratan analisis, dan tahap uji hipotesis. Analisis dilakukan pada kompetensi pengetahuan, sikap, dan keterampilan.

Statistik deskriptif adalah statistik yang berfungsi untuk mendiskripsikan atau memberikan gambaran terhadap objek yang diteliti. Analisis di lakuka melalui data sampel atau populasi sebagai mana adanya dan berlaku untuk umum. Statistik des kriptif, akan menyajikan data melalui tabel, per hitungan mean, median, modus, dan variasi kelom pok melalui rentang ${ }^{[12]}$.

Teknik persentase adalah salah satu teknik penilaian yang dapat digunakan untuk melihat per kembangan kompetensi siswa. Statistik deskriptif yang berfungsi untuk mendiskripsikan atau mem berikan gambaran terhadap objek yang diteliti me lalui data sampel atau populasi sebagaimana adanya dan berlaku untuk umum. Teknik persentase dapat digunakan untuk kompetensi pengetahuan, kompe tensi sikap, dan kompetensi keterampilan.

Uji hipotesis yang dilakukan yaitu uji perbandingan dua rata-rata. Uji perbandingan dua rata-rata yang dilakukan meliputi kompetensi peng etahuan, sikap, dan keterampilan. Tahapan uji per bandingan dua rata-rata dimulai dari uji normalitas, uji homogenitas, dan uji hipotesis.

Uji normalitas bertujuan untuk melihat apakah masing-masing sampel berasal dari data yang ter distribusi normal. Untuk menguji normalitas diguna kan uji Liliefors. Langkah uji liliefors mengurutkan data dari yang terkecil hingga yang terbesar. Men jadikan data yang telah diurutkan menjadi bilangan baku, lalu menggunakan daftar distribusi normal baku kemudian menghitung peluangnya.

Menghitung selisih $F\left(Z_{i}\right)-S\left(Z_{i}\right)$ yang kemudian ditentukan harga mutlaknya. Mengambil harga yang paling besar diantara harga mutlak selisih tersebut yang disebut $\mathrm{L}_{\mathrm{o}}$. Membandingkan nilai $\mathrm{L}_{\mathrm{o}}$ dengan nilai kritis $L_{t}$ yang terdapat dalam tabel nilai kritis $L$ untuk uji Liliefors pada taraf nyata $\alpha=0,05$. Kriteria data terditribusi normal jika $\mathrm{L}_{\mathrm{o}}<\mathrm{L}_{\mathrm{t}}^{[14]}$.

Uji normalitas yang telah dilakukan dilan jutkan dengan uji homogenitas. Uji Homogenitas ber tujuan untuk melihat apakah kedua kelompok data mempunyai varians yang homogen atau tidak. Untuk melakukan hal ini dilakukan uji $\mathrm{F}$, dengan langkahlangkah, mencari varians masing-masing data, kemu dian dihitung harga $\mathrm{F}$ dengan rumus:

$$
S^{2}=\frac{n \sum f_{i} X_{i}{ }^{2}-\left(\sum f_{i} X_{i}\right)^{2}}{n(n-1)}
$$

$\mathrm{F}_{h}$ merupakan hasil bagi varians yang besar dibagi dengan varians yang kecil. Jika harga $\mathrm{F}_{h}$ sudah didapatkan maka harga $\mathrm{F}_{h}$ dibandingkan dengan harga $\mathrm{F}_{t}$ yang terdapat dalam daftar distribusi dengan taraf signifikan $5 \%, d k_{\text {pembilang }}$ dan $d k_{\text {penyebut }}=n-1$. Bila harga $F_{t}>F_{h}$ berarti kedua kelas mempunyai varians yang homogen. Sebaliknya jika $F_{t}<F_{h}$, berarti kelompok sampel tidak mempunyai varians yang homogen.

Untuk menguji hipotesis tersebut, dilakukan uji perbandingan dua rata-rata. Jika sampel terdis tribusi normal dan kedua kelompok homogen, maka dilakukan uji t. Rumus uji t yaitu:

$$
t=\frac{\overline{X_{1}}-\overline{X_{2}}}{S \sqrt{\frac{1}{n_{1}}+\frac{1}{n_{2}}}}
$$

Kriteria pengujian diperoleh dengan mem bandingkan nilai $t_{\mathrm{h}}$ dengan cara Ho diterima jika memenuhi nilai $\mathrm{t}_{\mathrm{h}}$ berada diantara daerah penerimaan Ho dengan taraf signifikan 0,05, sedangkan untuk harga lain Ho ditolak. Perbedaan nilai $\mathrm{t}_{\mathrm{h}}$ dengan nilai $\mathrm{t}_{\mathrm{t}}$ akan dijadikan acuan untuk menyatakan hipotesis diterima atau tidak ${ }^{[13]}$. Persamaan hipotesis penerimaan Ho dapat dilihat sebagai berikut:

$$
-t_{1-1 / 2}<t_{h}<t_{1-1 / 2^{\alpha}}
$$

\section{HASIL PENELITIAN DAN PEMBAHASAN}

\section{Hasil Penelitian}

Hasil penelitian diperoleh dari data-data yang didapatkan di lapangan. Data yang didapatkan adalah kompetensi pengetahuan, kompetensi sikap, dan kom petensi keterampilan. Gambaran dari data penelitian ini uraikan sebagai berikut:

a. Pengaruh LKS Pada Kompetensi Pengetahuan

Penilaian hasil belajar siswa pada kompetensi pengetahuan didapatkan dari tes akhir secara tertulis dengan soal berbentuk pilihan ganda sebanyak 40 
butir soal. Tes akhir ini diberikan kepada kedua kelas sampel pada akhir dari kegiatan penelitian. Berda sarkan hasil perhitungan secara statistik di peroleh nilai rata-rata $(\mathrm{Xr})$, simpangan baku $(\mathrm{S})$, dan variansi $\left(\mathrm{S}^{2}\right)$ dari kedua kelas sampel. Hasil tersebut dapat dilihat pada Tabel 2.

Tabel 2. Nilai Rata-rata, Simpangan Baku, dan Variansi Kelas Sampel Kompetensi Pengetahuan

\begin{tabular}{|l|c|c|c|c|}
\hline \multicolumn{1}{|c|}{ Kelas } & $\mathrm{N}$ & $\mathrm{Xr}$ & $\mathrm{S}$ & $\mathrm{S}^{\mathbf{2}}$ \\
\hline Eksperimen & 32 & 52,02 & 10,99 & 120,73 \\
\hline Kontrol & 32 & 46,17 & 11,91 & 141,93 \\
\hline
\end{tabular}

Ada tiga hal yang dapat dijelaskan dari Tabel 2. Pertama, nilai rata-rata kompetensi pengetahuan siswa pada kelas eksperimen lebih besar dari kelas kelas kontrol. Kedua, Nilai simpangan baku kelas eks perimen lebih kecil dari pada nilai simpangan baku kelas kontrol, artinya kompetensi pengetahuan siswa pada kelas eksperimen lebih merata dari pada kelas kontrol. Ketiga, nilai variansi kelas eksperimen lebih rendah dari kelas kontrol, artinya kompetensi pengetahuan kelas kontrol lebih beragam dari pada kelas eksperimen.

Uji perbandingan dua rata-rata dilakukan untuk melihat perbedaan kompetensi kedua kelas berarti atau tidak. Uji perbandingan dua rata-rata dilakukan setelah dilakukan uji normalitas dan uji homogenitas kedua kelas sampel. Uji normalitas digunakan untuk melihat apakah kedua kelas sampel terdistribusi normal.

Hasil uji normalitas yang telah dilakukan didapatkan harga $\mathrm{L}_{\mathrm{o}}$ dan $\mathrm{L}_{\mathrm{t}}$ pada taraf nyata $(\alpha) 0,05$ untuk $\mathrm{n}_{1}=32$ dan $\mathrm{n}_{2}=32$ seperti pada Tabel 3 .

Tabel 3. Uji Normalitas Kompetensi Pengetahuan

\begin{tabular}{|c|c|c|c|c|c|}
\hline Kelas & $\mathrm{A}$ & $\mathrm{N}$ & Lo & Lt & Keterangan \\
\hline Eksperimen & \multirow{2}{*}{0,05} & 32 & 0,11 & 0,15 & Normal \\
\cline { 1 - 4 } Kontrol & & 32 & 0,13 & 0,15 & Normal \\
\hline
\end{tabular}

Berdasarkan data pada Tabel 3 diperoleh kesimpulan bahwa nilai $\mathrm{L}_{\mathrm{o}}$ pada kelas eksperimen sebesar 0,11 , sedangkan nilai $\mathrm{L}_{\mathrm{o}}$ pada kelas kontrol sebesar 0,13 . Kedua kelas sampel akan terdistribusi normal apabila harga $\mathrm{L}_{\mathrm{o}}<\mathrm{L}_{\mathrm{t}}$ pada taraf nyata 0,05 . Nilai $\mathrm{L}_{\mathrm{t}}$ pada taraf nyata 0,05 untuk $n=32$ didapatkan 0,15. Data normalitas yang didapat adalah nilai $\mathrm{L}_{\mathrm{o}}<\mathrm{L}_{\mathrm{t}}$, sehingga kedua kelas sampel sama-sama terdistribusi normal.

Setelah uji normalitas, langkah selanjutnya adalah melakukan uji homogenitas. Hasil perhitung an uji homogenitas dapat dilihat pada Tabel 4.

Tabel 4. Hasil Perhitungan Uji Homogenitas Kompe tensi Pengetahuan

\begin{tabular}{|c|c|c|c|c|c|}
\hline Kelas & $\mathrm{N}$ & $\mathrm{S}^{2}$ & $\mathrm{~F}_{\mathrm{h}}$ & $\mathrm{F}_{\mathrm{t}}$ & Keterangan \\
\cline { 1 - 3 } Eksperimen & 32 & 120,73 & \multirow{2}{*}{1,17} & \multirow{2}{*}{1,84} & \multirow{2}{*}{ Homogen } \\
\cline { 1 - 3 } Kontrol & 32 & 141,93 & & & \\
\hline
\end{tabular}

Tabel 4 menunjukkan hasil perhitungan uji homogenitas pada kedua kelas sampel. Hasil $\mathrm{F}_{\mathrm{h}}$ untuk kedua kelas sampel didapatkan sebesar 1,17. Kelas sampel akan memiliki varians yang homogen apabila nilai $F_{h}<F_{t}$. Hasil tersebut menunjukkan $F_{h}=1,17$, dan $\mathrm{Ft}=1,84$ sehingga $\mathrm{F}_{\mathrm{h}}<\mathrm{F}_{\mathrm{t}}$. Berarti kelas sampel memiliki varians yang homogen.

Uji hipotesis dilakukan setelah didapatkan hasil pada uji normalitas dan uji homogenitas. Uji hipotesis digunakan untuk mengetahui apakah hipo tesis diterima atau ditolak. Uji hipotesis yang dilaku kan menggunakan uji perbedaan dua rata-rata. Data yang didapat terdistribusi normal dengan variansi yang homogen, maka digunakan uji t. Uji t dilakukan untuk menentukan hasil hipotesis. Hasil perhitungan uji hipotesis dapat dilihat pada tabel 5 .

Tabel 5. Hasil Perhitungan Uji t Kompetensi Pengeta huan

huan
\begin{tabular}{|c|c|c|c|c|c|}
\hline Kelas & $\mathrm{N}$ & $\mathrm{Xr}$ & $\mathrm{S}^{2}$ & $\mathrm{t}_{\mathrm{h}}$ & $\mathrm{t}_{\mathrm{t}}$ \\
\hline Eksperimen & 32 & 52,02 & 120,73 & \multirow{2}{*}{2,04} & 2,00 \\
\hline Kontrol & 32 & 46,27 & 141,93 & & \\
\hline
\end{tabular}

Dari Tabel 5 dapat dideskripsikan nilai $\mathrm{t}_{\mathrm{h}}$ dari kedua kelas sampel. Nilai yang didapatkan setelah dilakukan analisis statistik sebesar $t_{h}=2,04$ Nilai $t_{t}$ untuk dk $=n-1$ sebesar $t_{t}=2,00$. Syarat pengujian terima Ho jika nilai $-t_{1-1 / 2^{\alpha}}<t<t_{1-1 / 2^{\alpha}}$. Harga $t$ yang didapat sebesar $-2,04<2,00<2,04$, dan harga $t$ tersebut tidak berada pada daerah penerimaan Ho sehingga dapat dikatakan $\mathrm{Hi}$ diterima pada taraf nyata 0,05 . Kurva penerimaan Ho dan penolakan Ho dapat dilihat pada Gambar 1.

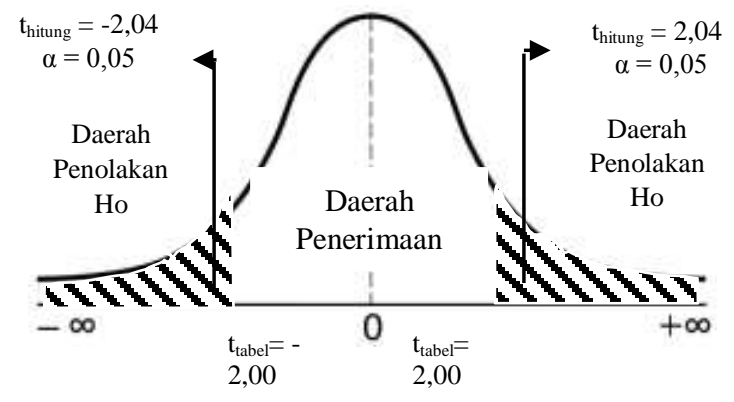

Gambar 1. Kurva Penerimaan dan Penolakan Ho pa da kompetensi Pengetahuan

Berdasarkan Gambar 1, memperlihatkan bahwa $t_{h}$ berada pada daerah penolakan Ho. Hasil analisis data dapat disimpulkan bahwa terdapat pe ngaruh penggunaan LKS IPA terpadu bermuatan literasi era digital dalam model pembelajaran konteks tual terhadapa kompetensi pengetahuan siswa kelas VIII SMPN 15 Padang.

b. Pengaruh LKS pada Kompetensi Sikap

Penilaian kompetensi sikap siswa diperoleh selama proses pembelajaran berlangsung. Data di am bil menggunakan lembar penilaian observasi yang dalam pelaksanaannya dibantu oleh observer. Penilai an kompetensi sikap terbagi atas 6 aspek penilaian. Keenam indikatornya yaitu ingin tahu, percaya diri, komunikatif, disiplin, komitmen inkuiri, dan kerja sama. Deskripsi dari data kompetensi sikap siswa ditunjuk kan dari skor total siswa setelah 4 kali treatmen yang dilakukan di dalam kelas. Deskripsi kompetensi sikap siswa dapat dilihat pada Tabel 6. 
Tabel 6. Nilai Rata-rata, Simpangan Baku, dan Variansi Kelas Sampel Kompetensi Sikap

\begin{tabular}{|c|c|c|c|c|}
\hline Kelas & N & Xr & S & S $^{\mathbf{2}}$ \\
\hline Eksperimen & 32 & 74,47 & 7,27 & 52,87 \\
\hline Kontrol & 32 & 65,69 & 8,66 & 75,10 \\
\hline
\end{tabular}

Data pada Tabel 6 dapat dijelaskan, pertama, nilai rata-rata kompetensi sikap siswa pada kelas eksperimen lebih tinggi dari kelas kontrol. Kedua, nilai simpangan baku kelas eksperimen lebih rendah dari pada nilai simpangan baku kelas kontrol. Berarti kompetensi sikap siswa kelas eksperimen lebih me rata dari pada kelas kontrol. Ketiga, nilai varians kelas eksperimen lebih rendah dari pada nilai varians kelas kontrol. Berarti kompetensi sikap siswa kelas kontrol lebih beragam dari pada kelas eksperimen.

Nilai kompetensi sikap siswa yang telah didaptkan selanjutnya dianalisis menggunakan uji perbedaan dua rata-rata.Analisis dilakukan untuk meli hat apakah terdapat perbedaan yang berarti pada kompetensi sikap siswa pada kedua kelas sampel.

Hasil yang didapatkan setelah uji normalitas dapat dilihat pada Tabel 7.

Tabel 7. Hasil Perhitungan Uji Normalitas Kom petensi Sikap

\begin{tabular}{|c|c|c|c|c|c|}
\hline Kelas & $\mathrm{A}$ & $\mathrm{N}$ & $\mathrm{L}_{\mathrm{o}}$ & $\mathrm{L}_{\mathrm{t}}$ & Keterangan \\
\hline Eksperimen & 0,05 & 32 & 0,06 & \multirow{2}{*}{0,15} & Normal \\
\hline Kontrol & 0,05 & 32 & 0,09 & & Normal \\
\hline
\end{tabular}

Pada Tabel 7 dapat dideskripsikan nilai $\mathrm{L}_{\mathrm{o}}$ pada kelas eksperimen sebesar 0,06 sedangkan nilai $\mathrm{L}_{\mathrm{o}}$ pada kelas kontrol sebesar 0,09. Kedua kelas sampel akan terdistribusi normal apabila didapatkan harga $\mathrm{L}_{\mathrm{o}}<\mathrm{L}_{\mathrm{t}}$ pada taraf 0,05 . Data yang didapatkan adalah nilai $\mathrm{L}_{\mathrm{o}}<\mathrm{L}_{\mathrm{t}}$, sehingga kedua kelas sampel sama-sama terdistribusi normal.

Hasil perhitungan uji homogenitas dapat di lihat pada Tabel 8.

Tabel 8. Hasil Perhitungan Uji Homogenitas pada Kompetensi Sikap

\begin{tabular}{|c|c|c|c|c|c|}
\hline Kelas & $\mathrm{N}$ & $\mathrm{S}^{\mathbf{2}}$ & $\mathrm{Fh}$ & $\mathrm{Ft}$ & Keterangan \\
\hline Eksperimen & 32 & 52,87 & \multirow{2}{*}{1,42} & \multirow{2}{*}{1,84} & Homogen \\
\cline { 1 - 3 } Kontrol & 32 & 75,10 & & & Homogen \\
\hline
\end{tabular}

Tabel 8 menunjukan hasil $\mathrm{F}_{\mathrm{h}}$ untuk kedua kelas sampel didapatkan sebesar 1,84. Kedua kelas sampel akan memiliki variansi yang homogen apabila nilai $\mathrm{F}_{\mathrm{h}}<\mathrm{F}_{\mathrm{t}}$. Hasil tersebut menunjukan bahwa 1,42<1,84 ,berarti kelas sampel memiliki variansi yang homogen untuk kompetensi sikap.

Data yang didapat terdistribusi normal dan memiliki varians yang homogen, sehingga digunakan uji $\mathrm{t}$ untuk menentukan hasil hipotesis. Hasil perhitungan uji hipotesis dapat dilihat pada Tabel 9. Tabel 9. Hasil Perhitungan Uji t Kompetensi Sikap

\begin{tabular}{|c|c|c|c|c|c|}
\hline Kelas & $\mathrm{N}$ & $\mathrm{Xr}$ & $\mathrm{S}^{2}$ & $\mathrm{t}_{\mathrm{h}}$ & $\mathrm{t}_{\mathrm{t}}$ \\
\hline Eksperimen & 32 & 74,47 & 52,87 & \multirow{2}{*}{4,39} & 2,00 \\
\hline Konrol & 32 & 65,69 & 75,10 & & \\
\hline
\end{tabular}

Dari tabel 9 dapat dijelaskan nilai $t_{h}$ dari kedua kelas sampel. Nilai yang didapatkan setelah dilakukan analisis statistik sebesar $\mathrm{t}_{\mathrm{h}}=4,39$ dan nilai $\mathrm{t}_{\mathrm{t}}$ untuk $\mathrm{dk}=\mathrm{n}-2$ sebesar $\mathrm{t}_{\mathrm{t}}=2,00$. Harga $\mathrm{t}$ yang didapatkan sebesar $-4,39<2,00<4,39$ dan harga $t$ tersebut tidak berapa pada daerah penerimaan Ho sehingga dapat dikatakan $\mathrm{Hi}$ diterima pada taraf nyata 0,05 . Kurva penerimaan Ho dan penolakan Ho dapat dilihat pada Gambar 2.

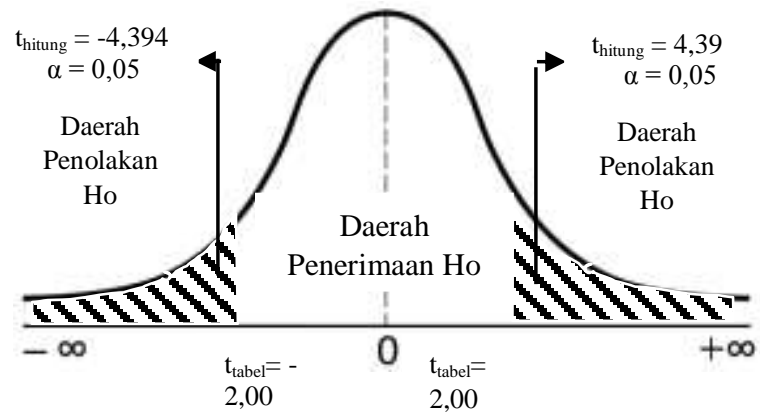

Gambar 2. Kurva Penerimaan dan Penolakan Ho Pa da Kompetensi Sikap

Dari gambar didapatkan penjelasan bahwa ni lai $t_{h}$ berada pada daerah penolakan Ho. Berdasar kan hasil uji hipotesis dapat dikemukakan bahwa ter dapat pengaruh yang berarti dari penggunaan LKS IPA terpadu bermuatan literasi era digital tema gerak dalam model pembelajaran kontekstual adaptif terha dap kompetensi sikap yang dimiliki siswa kelas VIII SMPN 15 Padang.

c. Pebedaan Kompetensi Keterampilan

Penilaian pada kompetensi keterampilan dila kukan pada kegiatan praktikum yang sedang berlang sung. Data penilaian diambil sebanyak 4 kali kegiat an praktikum berlangsung. Data kompetensi keteram pilan siswa didapatkan melalui rubrik penskoran, sehingga didapatkan nilai rata-rata $(\mathrm{Xr})$, simpangan baku (S), dan varians $\left(S^{2}\right)$ dari kedua kelas sampel seperti pada Tabel 10.

Tabel 10. Nilai Rata-rata, Simpangan Baku, dan Variansi Kelas Sampel Kompetensi Keterampilan

\begin{tabular}{|c|c|c|c|c|}
\hline Kelas & $\mathrm{N}$ & $\mathrm{Xr}$ & $\mathrm{S}$ & $\mathrm{S}^{\mathbf{2}}$ \\
\hline Eksperimen & 32 & 74,34 & 11,77 & 138,49 \\
\hline Kontrol & 32 & 67,91 & 13,641 & 186,09 \\
\hline
\end{tabular}

Penjelasan pada Tabel 10 adalah sebagai berikut. Pertama, nilai rata-rata kompetensi keteram pilan siswa kelas eksperimen lebih tinggi dari pada kelas kontrol. Kedua nilai simpangan baku kelas eksperimen lebih rendah dari kelas kontrol. Berarti, kompetensi keterampilan siswa kelas ekspeimen lebih merata dari kelas kontrol. Ketiga, nilai varians kelas eksperimen lebih rendah dari kelas kontrol. Berarti, kompetensi keterampilan siswa kelas kontrol lebih beragam dari kelas eksperimen.

Untuk melihat perbedaan kompetensi kedua kelas berarti atau tidak, maka dilakukan uji perban dingan dua rata-rata. Uji perbandingan dua rata-rata dilakukan setelah uji normalitas dan uji homogenitas kedua kelas sampel didapatkan. 
Uji normalitas untuk melihat apakah kedua kelas sampel terdistribusi normal. Hasil uji normal itas yang telah dilakukan didapatkan harga $\mathrm{L}_{\mathrm{o}}$ dan $\mathrm{L}_{\mathrm{t}}$ pada taraf nyata $(\alpha)=0,05$ untuk $n_{1}=32$ dan $n_{2}=32$. Hasil analisis yang didapatkan dilihat pada Tabel 11 . Tabel 11. Hasil Perhitungan Uji Normalitas pada Kompetensi Keterampilan

\begin{tabular}{|c|c|c|c|c|c|}
\hline Kelas & $\mathrm{A}$ & $\mathrm{N}$ & $\mathrm{L}_{\mathrm{o}}$ & $\mathrm{L}_{\mathrm{t}}$ & Keterangan \\
\hline Eksperimen & 0,05 & 32 & 0,11 & 0,1 & Normal \\
\cline { 1 - 4 } & 0,05 & 32 & 0,15 & 5 & Normal \\
\hline
\end{tabular}

Pada Tabel 11 dapat dideskripsikan bahwa nilai $\mathrm{L}_{\mathrm{o}}$ pada kelas eksperimen sebesar 0,11 sedang kan nilai $\mathrm{L}_{\mathrm{o}}$ pada kelas kontrol sebesar 0,15 . Kedua kelas sampel akan terdistribusi normal apabila didapatkan harga $\mathrm{L}_{\mathrm{o}}<\mathrm{L}_{\mathrm{t}}$ pada taraf 0,05 . Data yang didapatkan adalah nilai $\mathrm{L}_{\mathrm{o}}<\mathrm{L}_{\mathrm{t}}$, sehingga kelas sampel terdistribusi normal lalu dilakukan uji homogenitas.

Hasil perhitungan uji homogenitas dapat dilihat pada Tabel 12 .

Tabel 12. Hasil Perhitungan Uji Homogenitas pada Kompetensi Keterampilan

\begin{tabular}{|c|c|c|c|c|c|}
\hline Kelas & $\mathrm{N}$ & $\mathrm{S}^{\mathbf{2}}$ & $\mathrm{F}_{\mathrm{h}}$ & $\mathrm{F}_{\mathrm{t}}$ & Keterangan \\
\hline Eksperimen & 32 & 138,49 & \multirow{2}{*}{1,34} & \multirow{2}{*}{1,84} & Homogen \\
\cline { 1 - 3 } \cline { 6 - 6 } & 32 & 186,09 & & Homogen \\
\hline
\end{tabular}

Tabel 12 menunjukan hasil $\mathrm{F}_{\mathrm{h}}$ untuk kedua kelas sampel didapatkan sebesar 1,34. Kedua kelas sampel akan memilii variansi yang homogen apabila nilai $F_{h}$ $<\mathrm{F}_{\mathrm{t}}$. Hasil tersebut menunjukan $1,34<1,84$, berarti kedua kelas sampel memiliki variansi yang homogen.

Uji hipotesis yang untuk melihat perbedaan dari eksperimen. Uji yang digunakan yaitu uji perbedaan dua rata-rata. Data yang didapat terdis tribusi normal dan memiliki varians yang homogen, sehingga digunakan uji t untuk menentukan hasil hipotesis. Hasil perhitungan uji hipotesis dapat dilihat pada Tabel 13.

Tabel 13. Hasil Perhitungan Uji t Kompetensi Keter ampilan

\begin{tabular}{|c|c|c|c|c|c|}
\hline Kelas & $\mathrm{N}$ & $\mathrm{Xr}$ & $\mathrm{S}^{\mathbf{2}}$ & $\mathrm{t}_{\mathrm{h}}$ & $\mathrm{t}_{\mathrm{t}}$ \\
\cline { 1 - 4 } Eksperimen & 32 & 74,34 & 138,49 & \multirow{2}{*}{2,02} & \multirow{2}{*}{2,00} \\
\hline Konrol & 32 & 67,91 & 186,09 & & \\
\hline
\end{tabular}

Dari Tabel 13 Nilai $\mathrm{t}_{\mathrm{h}}$ yang didapatkan setelah dilakukan analisis statistik sebesar $t_{h}=2,02$ dan nilai $t_{t}$ untuk $d k=n-2$ sebesar $t_{t}=2,00$. Harga hipotesis yang didapatkan sebesar $-2,02<2,00<2,02$ dan harga $t_{h}$ tersebut tidak berada pada daerah pene rimaan Ho. Harga sehingga dapat dikatakan $\mathrm{Hi}$ diterima pada taraf nyata 0,05 , dilihat pada gambar 3 .

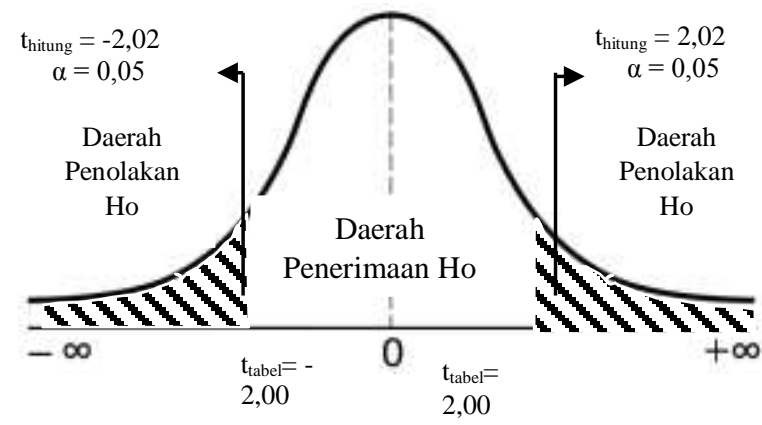

Dari gambar 3 didapatkan bahwa nilai $t_{h}=$ 2,02 dan $t_{t}=2,00$. Nilai $t_{h}$ berada pada daerah penolakan Ho. Berdasarkan analisis data da pat disim pulkan bahwa terdapat pengaruh yang berarti dari LKS IPA terpadu bermuatan literasi era digital tema gerak dalam model pembelajaran kontek stual adaptif terhadap kompetensi keterampilan siswa SMPN 15 Padang.

Berdasarkan analisis data pada kompetensi IPA terpadu aspek pengetahuan, sikap, dan keteram pilan, maka dapat dikemukakan bahwa terdapat pe ngaruh LKS IPA terpadu bermuatan literasi era digital tema gerak dalam model pembelajaran kon tekstual adaptif terhadap siswa kelas VIII SMPN 15 Padang pada taraf kepercayaan $95 \%$. Hal ini dikare nakan pada penggunaan LKS IPA Terpadu bermua tan literasi era digital tema gerak memberikan dampak positif terhadap kompetensi IPA Terpadu siswa dari ketiga aspek kompetensi yang diamati saat pembelajaran berlangsung di sekolah.

\section{Pembahasan}

Hasil penelitian pertama yang dicapai adalah pengaruh pengunaan LKS IPA terpadu bermuatan literasi era digital tema gerak dalam model pem belajaran kontekstual adaptif terhadap kom petensi pengetahuan siswa kelas VIII SMPN 15 Padang. Di dalam LKS IPA terpadu bermuatan literasi terdapat keterpaduan antar materi. LKS IPA terpadu ber muatan literasi era digital dengan jenis literasinya yaitu literasi fungsional, saintifik, dan visual. Indi kator literasi saintifik membuat siswa lebih mema hami konsep saintifik dan konteks saintifik ${ }^{[7]}$.

Melakukan pengamatan pada pembelajaran IPA sangat diperlukan. Indikator pada literasi visual membantu siswa dalam melakukan kegiatan penga matan. Indikator literasi visual yang dapat digunakan membantu meningkatkan kompetensi pengetahuan siswa adalah penafsiran visual dan pemanfaatan vi sual sehingga hasil yang didapat meningkat ${ }^{[6]}$.

Hasil penelitian kedua didapatkan bahwa terdapat pengaruh penggunaan LKS IPA terpadu bermuatan literasi era digital tema gerak dalam mo del pembelajaran kontekstual adaptif terhadap kom petensi sikap yang dimiliki siswa. LKS IPA terpadu membuat siswa aktif dan termotivasi dalam belajar. Prinsip penyusunan bahan ajar salah satunya yaitu dapat memotivasi siswa ${ }^{[15]}$. Motivasi belajar yang tinggi merupakan salah satu faktor penentuan keber hasilan belajar siswa.

Hasil penelitian ketiga dicapai atas peng gunaan LKS IPA terpadu bermuatan literasi era digital tema gerak dalam model pembelajaran kon tekstual adaptif terhadap kompetensi keterampil an yang dimiliki siswa kelas VIII. LKS bermuatan literasi era digital terdapat tiga jenis literasi yang dapat meningkatkan kompetensi keterampilan siswa yaitu literasi fungsional, literasi saintifik, literasi visual. Literasi fungsional atau literasi dasar yang 
dimiliki siswa dapat meningkat kan kemampuan membaca, menulis, menghitung, meng informasikan dan menggambarkan ${ }^{[16]}$. Pada literasi saintifik proses saintifik dapat meningkatkan kompetensi keteram pilan yang dimiliki siswa ${ }^{[6]}$.

Suatu upaya untuk meningkatkan keefektifan belajar siswa dalam pembelajaran adalah dengan memberi kesempatan kepada siswa untuk melakukan kegiatan kerja secara perseorangan ataupun secara kelompok dalam menyelesaikan lembaran-lembaran kerja siswa ${ }^{[15]}$. LKS IPA Terpadu bermuatan literasi era digital tema gerak direkomendasikan untuk guru dan siswa dalam pembelajaran. Guru dapat menggu nakan LKS IPA Terpadu bermuatan literasi era digital tema gerak sebagai salah satu alternatif dalam usaha meningkatkan kompetensi siswa. Guru dapat menggunakan model pembelajaran kontekstual adap tif sebagai salah satu alternatif yang bisa digunakan pada proses pembelajaraan. Rekomendasi utuk siswa yaitu dapat menggunakan LKS IPA Terpadu ber muatan literasi era digital tema gerak sebagai bahan pembelajaran untuk meningkatkan pemahaman yang dimiliki siswa.

Penelitian yang telah dilakukan memiliki beberapa kendala dan keterbatasan dalam pelaksana annya. Kendala ini dapat terjadi karena kekurangankekurangan yang dimiliki oleh peneliti. Kendala-ken dala yang dihadapi oleh peneliti adalah :

Pertama, materi pelajaran yang diterapkan dalam penelitian terbatas. Penelitian hanya terbatas pada tema gerak. Tema gerak materinya yang diba has adalah gaya dan usaha, gerak pada tumbuhan dan hewan, serta gerak pada manusia. Solusi alternatif untuk mengatasi kendala ini diharapkan ada peneli tian lanjutan pada tema yang lainnya.

Kedua, LKS yang digunakan bermuatan lite rasi fungsional, saintifik, dan visual. Salah satu ken dala pada penerapan literasi yaitu pada literasi fungsional. Pada indikator membaca, dan menulis terlihat rendahnya minat siswa dalam membaca dan menulis sehingga dalam pelaksanaannya masih menjadi kendala. Alternatif solusi yang dapat dila kukan pada kendala kedua adalah membiasakan ke giatan membaca disekolah setiap melakukan kegiatan pembelajaran dan kegiatan menulis di sekolah.

Ketiga, keterbatasan pada penggunaan tipe keterpaduan pembelajaran IPA. Tipe pembelajaran IPA terpadu yang digunakan dalam penelitian hanya lah satu tipe saja. Tipe yang digunakan yaitu tipe webbed atau model terjaring. Solusi yang dapat dila kukan untuk mengatasi kendala ini diharapkan peneliti lanjutan dapat menggunakan tipe pembelajar an terpadu yang lainnya seperti pembelajaran tipe terkait atau menggunakan keterpaduan di dalam dan beberapa disiplin ilmu.

\section{KESIMPULAN}

Berdasarkan analisis statistik yang dilakukan dapat dikemukakan kesimpulan dari penelitian ini.
Sebagai kesimpulan dalam penelitian adalah penggunaan LKS IPA terpadu bermuatan literasi era digital dalam model pembelajaran kontekstual adaptif memberi pengaruh yang berarti terhadap kompetensi siswa kelas VIII mencakup pengetahuan, sikap, dan keterampilan pada taraf kepercayaan $95 \%$ di SMPN 15 Padang.

\section{DAFTAR PUSTAKA}

[1] Pangesti, dkk. 2016. Desain Induk Gerakan Literasi Sekolah. Jakarta : Dirjen Pendidikan Dasar dan Menengah Kemendikbud RI.

[2] OECD-PISA. 2015. Science Competencies for Tomorrow's World. 1: Analysis. USA : OECDPISA.

[3] NCREL \& Metiri Group. 2003. enGauge $21^{\text {st }}$ century skills: Literacy in the Digital Age. USA: NCREL and Metiri.

[4] Trianto. 2014. Model Pembelajran Terpadu. Jakarta: Bumi Aksara.

[5] Rahayu, Putri, dkk. 2012. Pengembangan Pem belajaran IPA Terpadu dengan Meng gunakan Model Pembelajaran Problem Base Melalui Lesson Study. Jurnal pendidikan IPA Indonesia, (1), 63-70.

[6] Clay, M.M. 2001. Change Over Time in Chi ldren's Literacy Development. Portsmouth: Hei nemann.

[7] Budi Utami. 2016. Scientific literacy in science lesson. Vol (1) Jurnal prosiding ICTTE FKIP UNS. Hlm. 125-133. 16.

[8] Asrizal. 2017. Model Pembelajaran Kontekstual Adaptif. Padang: FMIPA UNP.

[9] Asrizal, Ali Imran, Azwar Ananda, Festiyed. 2017. Effectiveness of Adaptive Contextual Learning Model of Integrated Science by Integrating Digital Age Literacy on Grade VIII Students. IOP Conf. Series.

[10] Esti Aprilia Usman, Asrizal, Zulhendri Kamus. 2017. Pengembangan IPA Terpadu Menginteg sikan Literasi Saintifik pada Materi Gerak dalam Kehidupan untuk Siswa Kelas VIII SMP. Pillar of Physics Education. Vol (9). Hlm. 25-32.

[11] Djusmaini Djamas. 2015. Metodologi Penelitan Pendidikan Fisika. Padang: UNP

[12] Sugiyono. 2017. Metode Penelitian Kuantitatif, Kualitatif, Dan R\&D. Bandung : Alfabeta

[13] Suharsimi Arikunto. 2008. Belajar dan Pembe lajaran Teori dan Konsep Dasar (edisi revisi). Bandung: Remaja Rosdakarya

[14] Sudjana. 2002. Metode Statistika. Bandung: Tarsito.

[15] Permendikbud. 2014. Modul Pelatihan Imple mentasi Kurikulum 2013 Mata Pelajaran IPA SMP/MTS. Jakarta: Kemendikbud.

[16] Sumiati \& Asra. 2007. Metode Pembela jaran. Bandung : Wacana Prima 